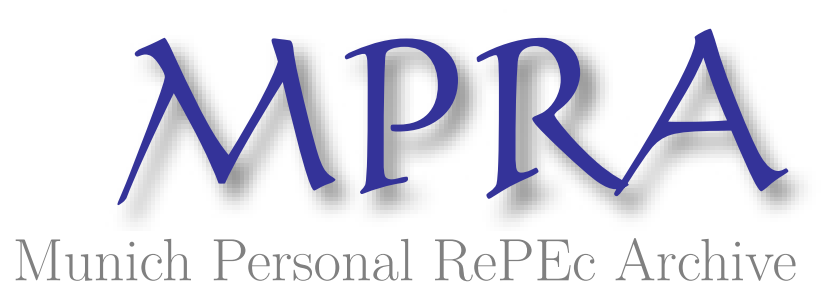

\title{
The Impact of the Reformation on the Economic Development of Western Europe
}

Sheremeta, Roman and Smith, Vernon

7 May 2017

Online at https://mpra.ub.uni-muenchen.de/87220/

MPRA Paper No. 87220, posted 15 Jun 2018 13:22 UTC 


\title{
The Impact of the Reformation on the Economic Development of Western Europe
}

\author{
Roman M. Sheremeta ${ }^{a, b, *}$ \\ Vernon L. Smith ${ }^{b}$ \\ a Weatherhead School of Management, Case Western Reserve University \\ 11119 Bellflower Road, Cleveland, OH 44106, USA \\ ${ }^{\mathrm{b}}$ Economic Science Institute, Chapman University \\ One University Drive, Orange, CA 92866, USA
}

May 27, 2017

\begin{abstract}
The Protestant Reformation is a vivid example of how religious transformation could set in motion institutional changes, leading to profound consequences for economic and political development. Although economists and other social scientists agree that there is a strong relation between the Reformation and economic growth, there is an active discussion as to what are the causal pathways connecting Protestantism to long-run economic success. We discuss the causal pathways that received substantial empirical support in academic literature. Some of them, such as "work ethic" and entrepreneurial spirit of Protestants, were originally suggested by Max Weber, while others, such as religious freedom and education, are deeply grounded in economic theory. More recently, other causal pathways have been suggested, such as social ethic, civil society, and institutional changes. We bring our view of these pathways.
\end{abstract}

Keywords: Reformation, religion, economic development

* Corresponding author: Roman M. Sheremeta, rms246@case.edu

We have benefited from helpful comments of Jared Rubin. Also, we wish to thank the Economic Science Institute and the Weatherhead School of Management for continual research support. Any errors are ours. 


\section{Introduction}

The economic consequences of the Protestant Reformation are of wide ranging importance for debates concerning the emergence of economic growth in Western Europe. In general, economists and other social scientists agree that there is a strong relation between the Reformation and economic growth (Becker et al., 2016). There is also an active discussion as to what are the causal pathways connecting Protestantism to long-run economic success. In this chapter we review the main research findings in economics on the topic of the Protestant Reformation and its socio-economic consequences.

A distinguishing feature of economics in comparison with other social sciences is a strong focus of economic research on causal relationships as distinct from correlation. Any student who has taken an introduction to economics or a statistics class heard that "correlation does not imply causation." Just because the two variables are correlated (that is, they fluctuate in tandem), does not itself prove that they are meaningfully related to one another, or that one is causing another. Let us consider the following example: if you saw the statistics that for each year of education a person in the United States earns approximately $\$ 4,000$ more per year, you might be tempted to conclude that education leads to higher earnings. However, it could be the case that smarter people choose to go to the university, and smarter people will be able to find better jobs not necessarily because of their education but simply because they are smarter. So, how can we find out if the value added by education is specifically beneficial for future earnings? ${ }^{1}$ To answer this, and other questions, economists rely on sophisticated methods of econometric analysis, which allow them to make not only correlational but also causal inferences. We will not go into the details of these methods, but we will be making this distinction when a particular study finds a correlation versus a causal relation.

\section{How did the Protestant Reformation Impact Economy}

Perhaps one of the first people to recognize the role the Protestant Reformation played in the economic development of Western Europe was Max Weber. While living in Prussia, he observed that most Protestant cities were better off than Catholic cities. Max Weber not only noted the correlation between Protestantism and positive economic outcomes, but he also suggested a causal mechanism by which this correlation could have occurred. In his work, The Protestant Ethic and the Spirit of Capitalism, Weber (1905) argued that the Reformation influenced European society by changing the values and ethics of people. Although Weber's thesis has been challenged throughout the years by R.H. Tawney (1926), Kurt Samuelsson (1957), and more recently by Deirdre McCloskey (2010), it is a

\footnotetext{
${ }^{1}$ The research on this subject finds that education indeed makes a causal impact on individual earnings (Card, 1999).
} 
fairly well accepted proposition that Weber was right about the causal connection between Protestantism and economic success, if not about why it was so.

To demonstrate that the Protestant Reformation had a causal impact on economic outcomes, Sascha Becker and Ludger Woessmann (2009) used the data from 452 counties in 1871 Prussia. Their careful econometric analysis showed that Protestants had significantly higher incomes than Catholics, and that the difference was mainly due to the Reformation. However, unlike Weber, their preferred explanation was that "Protestantism led to substantially higher literacy, which in turn led to economic progress."

\section{Figure 1: Welfare ratios of workers in Protestant and Catholic cities, 1500-1899}

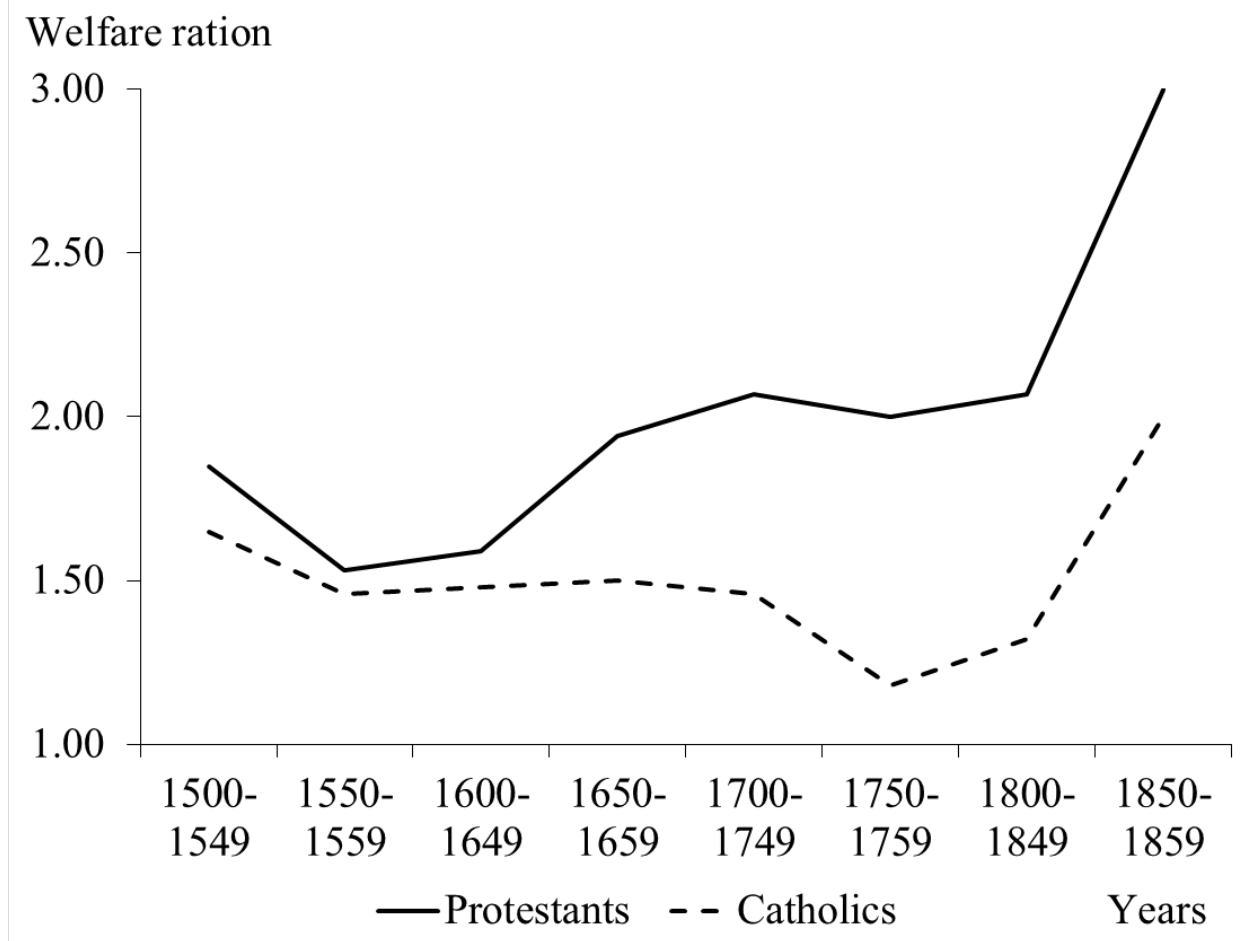

Source: The data are taken from Allen (2001).

The positive causal impact of Protestantism on economic success extends well beyond the borders of Prussia. Consider Figure 1, which shows the "welfare ratios" of workers in 17 European cities (6 Protestant cities and 11 Catholic cities) from the 16 th through 19 th century. ${ }^{2}$ A welfare ratio is the ratio of a worker's wages relative to how much it costs to buy minimal resources that are necessary for a worker's subsistence. A welfare ratio of 1 means that workers are just living at the subsistence level, while a ratio of 2 indicates that workers can buy twice the level of resources necessary for

2 The figure is built using the data from Allen (2001). The six Protestant cities are Amsterdam, London, Strasbourg, Augsburg, Leipzig, and Hamburg. The eleven Catholic cities are Antwerp, Florence, Naples, Valencia, Madrid, Paris, Munich, Vienna, Gdansk, Krakow, and Warsaw. 
subsistence. It is clear from the figure that beginning in the 17th century, workers in the Protestant cities had significantly better economic conditions than their Catholic counterparts.

Figure 2: The impact of different religious groups on economic welfare

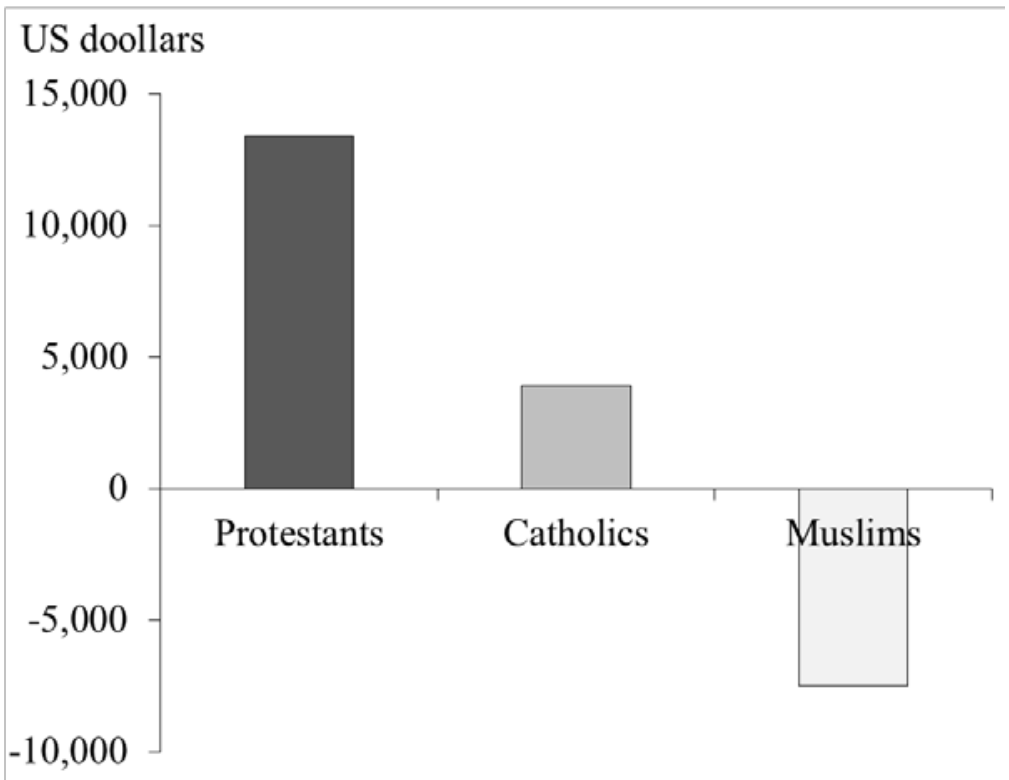

Source: The data are taken from Rubin (2017).

The correlation presented in Figure 1 is still apparent today. Jared Rubin (2017) used the real (in 2010 US dollars) per capita gross domestic product for different countries to show the impact of different religious groups on economic welfare of a country. Figure 2 summarizes the results of his estimation. A country made up of only Protestants is \$13,406 wealthier per person, on average, than a country with zero Protestants. There is also a positive effect for Catholicism, but it is much smaller: a country made up of only Catholics is $\$ 3,900$ wealthier per person than a country with zero Catholics. On the other hand, a country made up of only Muslims is $\$ 7,509$ poorer per person than a country with zero Muslims (even after accounting for the oil-rich nations of the Persian Gulf). ${ }^{3}$

The patterns in the data that we showed so far demonstrate that there is indeed a positive correlation between Protestantism and wealth. But even more important, economic researchers showed that not only is there a positive correlation between Protestantism and wealth, but also that there is a causal connection between Protestantism and economic success (Blum and Dudley, 2001; Becker and Woessmann, 2009; Chen et al., 2014; Rubin, 2017). In summary, the existing research points out that Weber's observation regarding the positive impact of the Protestant Reformation is accurate.

\footnotetext{
${ }^{3}$ These estimated numbers come from a multi-variate regression analysis in which the number of Protestants, Catholics and Muslims are used as independent variables.
} 


\section{The Causal Pathways Connecting the Reformation to Economic Growth}

While there is an agreement among economists and other social scientists that the Protestant Reformation had a positive impact on economic growth in Western Europe, there is an active discussion as to what are the causal pathways connecting Protestantism to long-run economic success. In what follows, we discuss the causal pathways that received substantial empirical support in academic literature. The challenge is to identify the characteristics or defining features of Protestantism that accounts for its measured higher economic performance. Figure 3 provides a schematic demonstration of these pathways. Some of them, such as "work ethic" and entrepreneurial spirit of Protestants, were originally suggested by Max Weber, while others, such as religious freedom and education, are deeply grounded in economic theory. More recently, other causal pathways have been suggested, such as social ethic, civil society, and institutional changes. We bring our view of these pathways, starting with religious freedom.

Figure 3: Causal pathways connecting the Protestant Reformation to economic growth

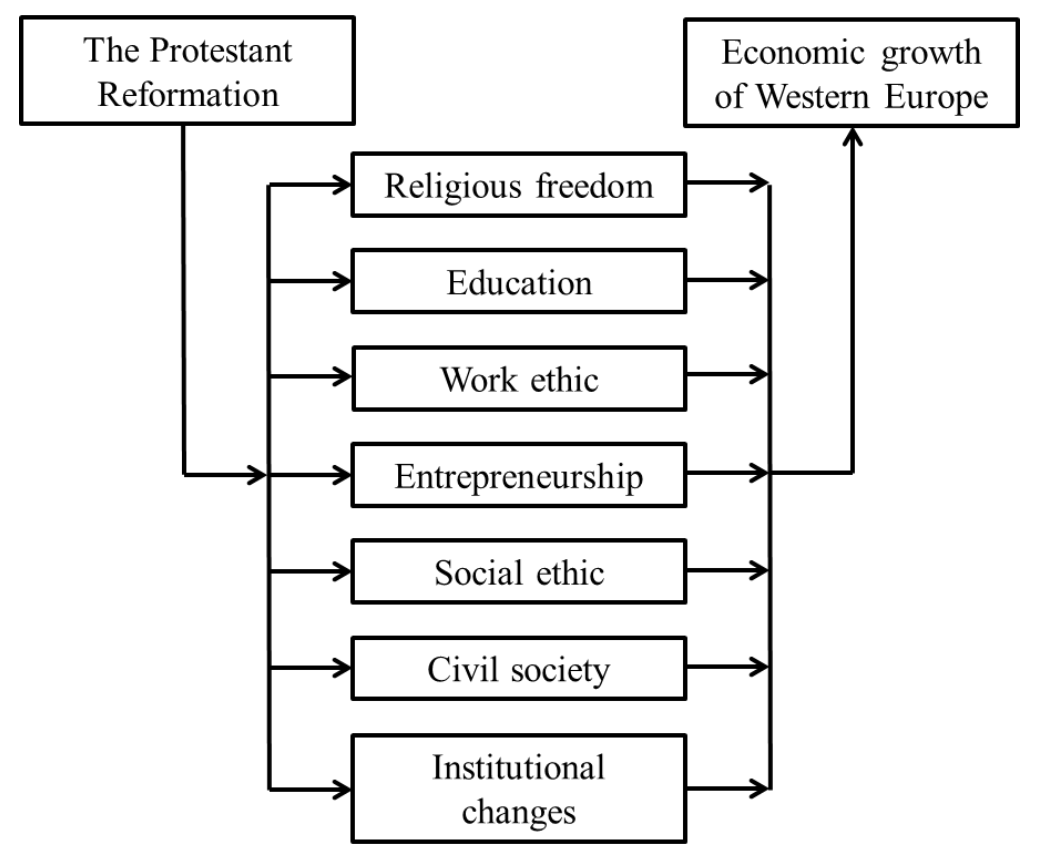

\subsection{Religious freedom}

Perhaps one of the central ideas of economics is that competition is beneficial to economic development by encouraging innovation (Schumpeter, 1942) and efficient allocation of resources (Smith, 1962; Fama, 1970; Arrow, 1974). Therefore, governments should strive to create an environment that maximally encourages competition, while discouraging any attempts of creating monopolies. Monopoly is routinely encouraged when governments impose restrictions on entry of new 
forms of economic activity. Incumbent suppliers lobby government to limit or prevent entry by innovators. Thus governments intervene to limit entry by UBER and LYFT that directly link customers with independent suppliers of local auto transportation. These entrants compete with taxi companies, car rental companies, airport parking, and even car ownership. The same idea of detrimental impact of monopolies applies when talking about religion (James, 1989; Stark and Iannaccone, 1994; Gill, 1998). Indeed, it is a well-documented empirical fact that societies with prevalent religious monopolies are characterized by slow economic growth, widespread poverty, and high rates of corruption (Norris and Inglehart, 2004; Ekelund et al., 2006).

Medieval Roman Catholic Church in Western Europe enjoyed exclusive monopolistic rights on religion. It was backed by the secular power of the state, actively enforcing orthodox claims, sanctioning excommunicates, and punishing heretics (Becker et al., 2016). Such monopolistic barriers, enforced by orthodox teachings and criminal persecution, prevented entry of rival ideas (Miller, 2002; Stark and Iannaccone, 1994). Perhaps the most cost-efficient barrier imposed by the Roman Catholic Church was the idea that the route to eternal salvation was only through the Holy Roman Church. This monopolistic right over the message of salvation allowed the Catholic Church to raise revenue by selling indulgences from sin, not only on behalf of the living, but also on behalf of the dead. Martin Luther was appalled by the implication that salvation of a human soul could be bought with money, and as a reaction on October 31, 1517 he nailed his famous Ninety-Five Theses to the door of the All Saints Church at Wittenberg. This day marked the beginning of the Protestant Reformation (Bainton, 1950; Oberman, 1989). One of the five foundational solae of the Reformation was Sola Christus (Latin: "Christ alone") - the teaching that Christ is the only mediator between God and man, and that there is salvation through no other. The teaching that salvation is a free gift of God (and not a product that could be bought from a monopolist) paved a way for religious freedom. Within just a decade, new religious groups were formed that ultimately became known as Lutherans, Presbyterians, Methodists, Baptists, Pentecostals, and many others.

There are many reasons why religious freedom (as opposed to religious monopoly) is good for economic development. First, religious freedom reduces corruption (North et al., 2013). Economists have long recognized that monopolies are more likely to engage in unproductive and often illegal activities, resulting in economic losses. ${ }^{4}$ Therefore, it is not surprising that there is a strong correlation

\footnotetext{
${ }^{4}$ One of the central characteristics of monopolies is that they are prone to rent-seeking, i.e., monopolies spend substantial resources while lobbying for government to impose regulations on competitors (Krueger, 1974; Tullock, 1980). A large literature in experimental economics shows that rent-seeking can be even more extensive than predicted by the standard economic theory (Dechenaux et al., 2015; Sheremeta, 2013, 2015, 2016).
} 
between corruption and religious monopolies. Just to give you an example, eight of the ten most corrupt countries are also among the countries with the highest governmental restrictions on religious liberty (based on the 2011 Government Restrictions on Religion Index). Second, religious freedom reduces conflict within a society, encouraging tolerance and respect for different beliefs. Indeed, Pew Research Center shows that the increase in religious freedom is associated with the decrease in social hostilities. Third, religious freedom promotes the protection of civil and human rights, such as freedom of speech, press and assembly (Grim and Finke, 2011). These rights are essential for the exchange of ideas - a very important component of an innovative economy.

\subsection{Education}

Another pathway through which the Protestant Reformation contributed to economic success of Western Europe is through education. Economists and others have long recognized the potential value education may have on economic growth. Following the classical contributions by Robert Barro (1991) and Greg Mankiw and co-authors (1992), a large economic literature found a significant positive correlation between education and economic growth (Hanushek and Woessmann, 2010). Although it is not an easy task, economists were also able to show, using theoretical modeling and various econometric techniques, that education has a causal impact on economic development - that is, education leads to economic development (Hanushek and Woessmann, 2012; Hanushek, 2016). Perhaps as important is the fact that it is not simply the number of years of education that matters, but the quality of education, as measured by mathematics and science test scores (Hanushek and Kimko, 2000). The immediate implication is that any country can achieve better economic outcomes by providing educational opportunities for its citizens.

Why was education important for Protestants? Martin Luther wanted all Christians to read the Bible. One of the five foundational solae of the Protestant Reformation was Sola Scripture (Latin: "Scripture alone") - the teaching that the Christian Scriptures are the supreme authority in all matters of doctrine and practice. However, for Christians to be able to read the Bible, it was necessary to increase their literacy rate. Historical data shows that Protestants indeed were able to do this. Using the 1871 Prussian census data, Sascha Becker and Ludger Woessmann (2009) showed that all-Protestant counties had a significantly higher literacy rate than all-Catholic counties. Moreover, they were able to show that this difference in literacy rates was caused by the Reformation. Not only Protestant cities had higher literacy rates on average, but also a smaller gender gap in literacy (Becker and Woessmann, 2008). In support of this, Figure 4 shows that in 1871 Prussia, Protestant men had a literacy rate of 
93.4 percent compared to 84.8 percent for Catholic men, while for women had a literacy rate of 88.8 percent compared to 78.5 percent.

\section{Figure 4: Literacy rates by religious group and gender, 1871}

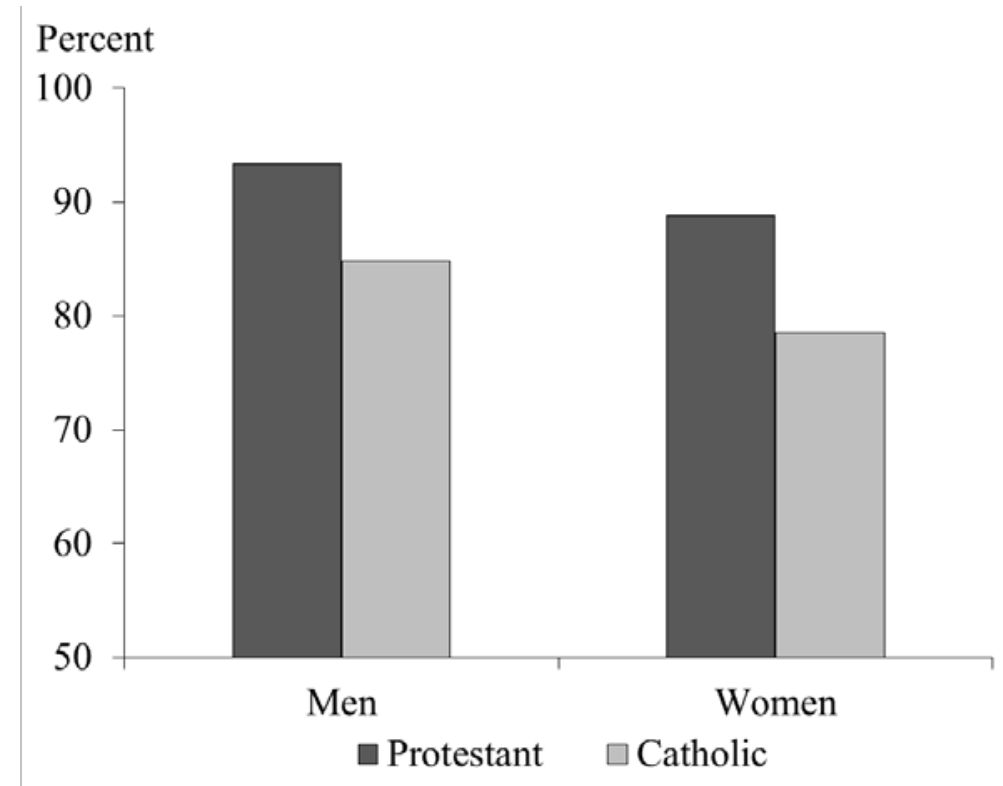

Source: The data are taken from Becker and Woessmann (2008).

The Reformation not only had a significant impact on literacy rates, but also a significant impact on overall education. Boppart and co-authors (2013) used the data from the 19th century collected from pedagogical examinations in Switzerland. Standardized tests were compulsory for every male citizen and examined reading, writing, mathematics, and history. Their analysis showed that Protestants not only excelled in reading, but also on other cognitive tests. The higher educational attainments by Protestants also had significant positive spillovers. Francisco Gallego and Robert Woodberry (2010) provided evidence that regions in former Colonial Africa in which Protestant missionaries dominated have higher literacy rates than those where Catholic missionaries dominated. Ying Bai and James Kung (2015) provided similar evidence for China, Rachel McCleary (2013) for Korea, and Federico Mantovanelli (2014) provided evidence for India.

In summary, the above mentioned research studies point out that the Protestant Reformation had a significant impact on education, which in turn spurred economic growth. There are many reasons why education is important for economic development. First, education increases labor productivity (Barro, 1991; Mankiw et al., 1992). Enrico Moretti (2004) showed that factories in cities with more educated people are more productive than similar factories in cities with less educated people. Second, education fosters technological innovation and new knowledge creation (Lucas, 1988; Romer, 1990). Finally, education brings other external benefits, which could further advance economic development. 
For example, it has been shown that more educated individuals make better decisions about health, marriage, and parenting (Oreopoulos and Salvanes, 2011). Education also affects individual preferences, making people more patient, more goal-oriented, and less likely to engage in risky behavior. All of these behaviors could be linked with better economic outcomes.

\subsection{Work ethic}

Max Weber famously claimed in his classic essay that Protestantism cultivated preferences for hard work and thus resulted in greater economic posterity (Weber, 1905). The argument that hard work leads to economic success is grounded in classical economic theory of production and growth (Solow, 1956). The theory shows that increasing work hours, while holding the other factors constant and assuming no technological change, will increase economic output. The obvious question is whether Protestants indeed had a different "work ethic?"

One of the foundational solae of the Protestant Reformation was Sola Gratia (Latin: "only grace") - the teaching that salvation comes by divine grace or "unmerited favor" only, not as something that can be earned by hard work. For Protestants, beginning with Martin Luther, diligent work was seen as a response to the grace of God, as well as a God given duty which benefits both the individual and society as a whole.

In 2003, Niall Ferguson published an article in the New York Times, where he pointed that the data from the Organization for Economic Cooperation and Development seems to confirm the Protestant work ethic hypothesis: "The experience of Western Europe in the past quarter-century offers an unexpected confirmation of the Protestant ethic. To put it bluntly, we are witnessing the decline and fall of the Protestant work ethic in Europe. This represents the stunning triumph of secularization in Western Europe - the simultaneous decline of both Protestantism and its unique work ethic" (Ferguson, 2003). There is other anecdotal evidence suggesting that Protestant work ethic is a driving force behind economic success of many countries (Mills, 2013; Bresiger, 2014).

To test Weber's "work ethic" hypothesis more formally, Jork Spenkuch (2016) used micro-data from Germany, which shows that Protestants work longer hours than Catholics. Using an instrumental variable method, he provided causal evidence that Protestantism induced individuals to work approximately 3.5 hours more per week. Christoph Basten and Frank Betz (2013) also provided strong empirical support for Weber's hypothesis by using the data from Switzerland. Finally, Andre van Hoorn and Robbert Maseland (2013) used the World Value Survey to show that unemployment brings more dissatisfaction to Protestants, confirming that Protestants value work more than other religious 
groups. Together, these research studies suggest that the Protestant Reformation had a significant impact on economic development of Western Europe by changing values and orientations of Europeans toward hard work. ${ }^{5}$

\subsection{Entrepreneurship and "the spirit of capitalism"}

Another famous claim that Max Weber made in his seminal work is that Protestantism was central to the rise of what he called the "spirit of capitalism." He argued that for Protestants occupation is a calling from God, and thus for some it may be a God's calling to be an entrepreneur. Entrepreneurship, of course, is one of the fundamental features of capitalism and a market economy. It is also one of the factors of production in economic theory (Clark, 1899; Hayek, 1937).

The economic and psychology literature on entrepreneurship suggest that the fundamental determinants of the individual decision to become an entrepreneur are determination, resilience, selfconfidence, a sense of independence, and a sense of life (Cuervo, 2005; Parker, 2005). All these attributes may be significantly influenced by the ethical principles inherent in Protestantism and Catholicism. Reviewing the existing literature, Luca Nunziata and Lorenzo Rocco (2016) conclude that "tenets of Protestantism should lead adherent Protestants to be more determined to achieve success, more willing to work hard, more disciplined, and more focused on their own self-realization than are Catholics." These attributes in turn should encourage Protestants to be more entrepreneurial.

To examine the nexus between religion and rates of entrepreneurship, Luca Nunziata and Lorenzo Rocco (2016) used the data from Switzerland. Consistent with Weber's hypothesis and their own assessment of the existing literature, they found that Protestants are significantly more likely to be entrepreneurs than Catholics. They reached the same conclusion looking at the data from the European Social Survey (Nunziata and Rocco, 2014). In a related research study, Cornelius Rietveld and Elco van Burg (2014) provided evidence that Protestant entrepreneurs are more likely to have a view that their duty is to add value to society through their work and that "their work is a calling from God."

\subsection{Social ethic: trust and honesty}

Weber's idea that the Protestant Reformation may have triggered a certain mental revolution, lead others to examine if Protestants have a stronger "social ethic" which could be another pathway through which the Reformation impacted economic development of Western Europe. Consistent with

\footnotetext{
${ }^{5}$ The fact that Protestants tend to have fewer religious holidays could be also suggestive of Weber's hypothesis (Ekelund et al., 2006).
} 
this idea, a number of independent research studies showed that Protestants have a higher level of trust (Inglehart, 1999; Uslaner, 2002; Guiso et al., 2003; Delhey and Newton, 2005; Bjornskov, 2007) and lower level of corruption (Treisman, 2000; Guiso et al., 2003; Woodberry, 2004; Arrunada, 2010; Chen et al., 2014). Trust and honesty, of course, are important factors for economic growth. Figure 5 shows the correlation between gross national product and trust level in 1991, taken from the World Value Survey, for 25 European countries. There is a clear positive relation, showing that countries with higher trust level have wealthier economies.

Figure 5: Gross national product and trust level, 1991

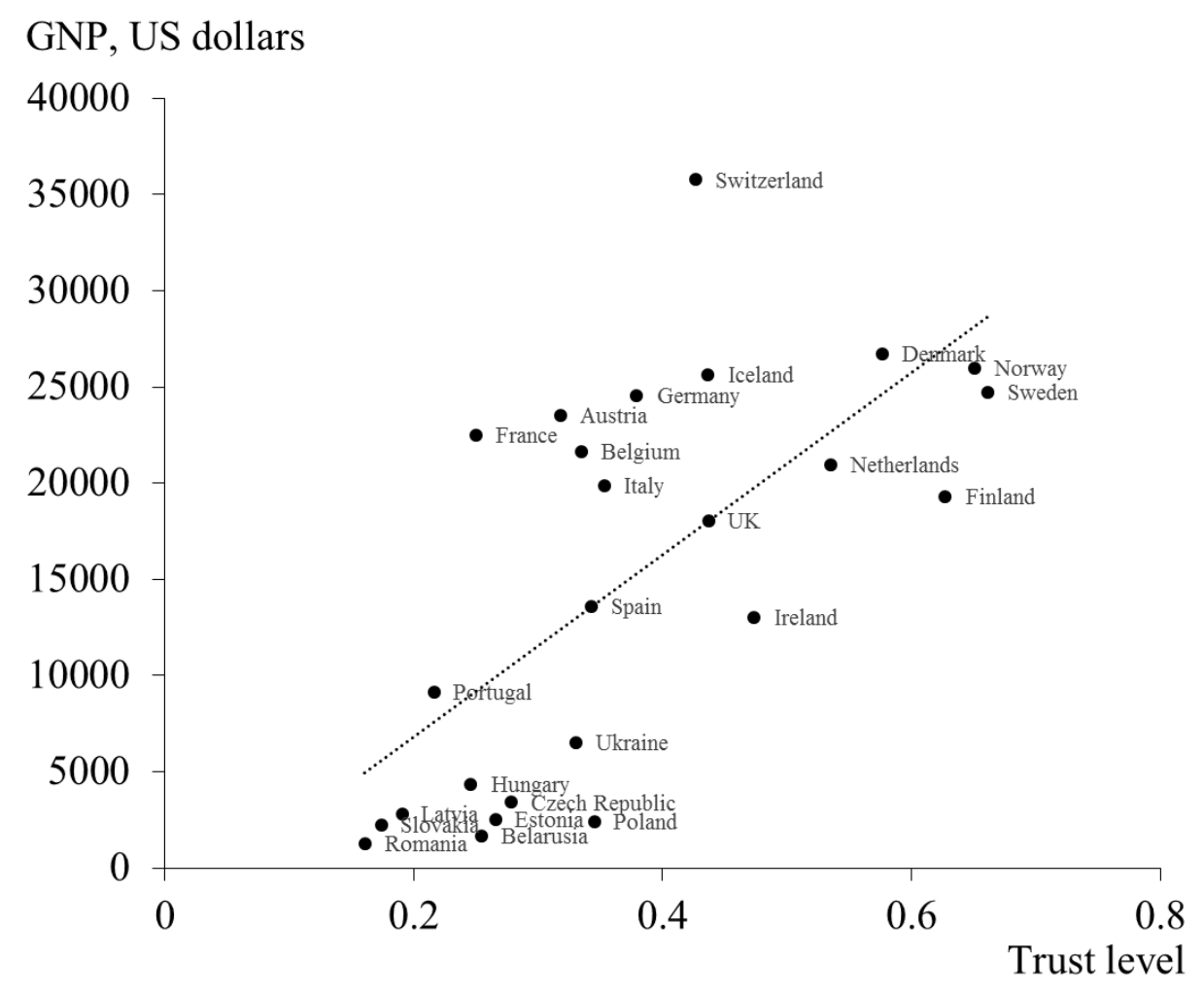

Source: The data are taken from La Porta et al. (1997).

Benito Arrunada (2010) used the data from a large international sample, to study how people from different religious groups responded to a question: "Generally speaking, would you say that people can be trusted or that you can't be too careful in dealing with people?" He found that Protestants are more likely to provide affirmative answer to this question than Catholics. Similarly, Luigi Guiso and co-authors (2003) used the World Value Survey to show that Protestants have higher levels of trust and are less willing to break the law. Given that trust has been shown to have a causal and positive effect on economic development (Knack and Keefer, 1997; Glaeser et al., 2000; Zak and Knack, 2001; Tabellini, 2010; Algan and Cahuc, 2013) and cooperation (La Porta et al., 1997; 
Burnham et al., 2000; Rietz et al., 2013), we can conclude that trust is one of the causal pathways connecting Protestantism to long-run economic success.

The same research studies by Benito Arrunada (2010) and Luigi Guiso and co-authors (2003) showed that Protestants not only have a higher level of trust, but in comparison to Catholics, they are also more likely to honestly report misbehaviors of others. Specifically, they found that Protestants are significantly less tolerant of tax fraud than Catholics, and Protestants are less willing to cover up for their delinquent friends in dealings with the police. Robert Woodberry (2004) showed that countries

that were significantly influenced by Protestant missionaries have a significantly lower level of corruption. Corruption, of course, has been shown to have a negative effect on economic development (Mauro, 1995; Treisman, 2000).

Together, these findings, as well as findings from other research studies (Stulz and Williamson, 2003; Barro and McCleary, 2003; Chen et al., 2014), support Weber's idea that the Protestant Reformation may have fostered certain moral codes and social values that are conducive to economic growth. In fact, Yuyu Chen and co-authors (2014) attribute part of China's recent economic success to disseminations of Protestant social values by western missionaries.

\subsection{Civil society}

One of the main characteristics of highly developed Western countries is the presence of civil society. In civil society, citizens voluntarily organize activities and services for themselves and other people. A good example of a country with a strong civil society is the United State of America. Alexis de Tocqueville in Democracy in America, used the phrase the "art of association" to describe Americans' propensity for civil engagement (de Tocqueville, 1935). Strong civic engagement of American people is well demonstrated by the fact that, according to the 2014 World Giving Index, the United States is the most charitable country in the world, with Americans donating approximately 2 percent of gross domestic product.

The main principles of the American civil society were laid out in the 1776 Declaration of Independence and the 1789 Constitution of the United States of America. Where did the American founding founders get these principles? To give you a hint, out of the 55 delegates to the 1787 Constitutional Convention, 49 were Protestants (Lambert, 2003). Of course, we do not want to make any strong causal inferences from this observation, but it is clear that the formation of the American civil society was strongly influenced by Christian Protestant values (Wills, 1979; Amos, 1989). 
Researches have shown that Protestant traditions indeed have a causal impact on development of civil society in different countries. After reviewing the academic literature on this topic, Robert Woodberry (2004) concluded that "in every society" there is strong evidence that "Protestant groups are more active than other religious groups in forming and supporting non-profit organizations." 6 The more active civic engagement of Protestants has been documented in America (Curtis et al., 2001), Canada (Lam, 2002), Africa (Anheier, 1989), Japan (James, 1986), Thailand (Pongsapich, 1998), as well as other countries (Anheier and Salamon, 1998; Curtis et al., 2001). In all these countries, Protestant missionaries played an important role in fostering the growth of organizational civil society (Woodberry, 2004). They brought new forms of social organization to the nonwestern world. Not only missionaries preached the Gospel (good news that Jesus Christ forgives sins) and set up religious organizations, but they also tried to reform what they viewed as abuses in other societies (Deol, 2000; van der Veer, 2001).

The cornerstone principle of civil society is voluntary cooperation - the willingness to help and to use one's free time for the benefit of others. Such norms of cooperation are related to virtues like honesty, trust, reciprocity, and the like (Cook et al., 2005; McCarter and Sheremeta, 2013; Schniter et al., 2013), thus potentially reducing transaction costs in the economic sphere (Fukuyama, 2001). Also, greater civil engagement leads to closer monitoring of the government (Putnam, 1993) and lower corruption (Treisman, 2000). Not surprisingly, therefore, civil society has been linked to economic growth (Fukuyama, 2001; Martinussen, 2015). After examining the data from 85 countries, Daniel Treisman (2000) concluded that one of the potential reasons for the success of Protestant countries is that "Protestant traditions... lead to a more vibrant, autonomous civil society." The Protestant Reformation, of course, was at the root of forming Protestant values.

\subsection{Institutional changes: governance, politics and law}

Recently, social scientists have begun to consider the role that the Protestant Reformation played in the evolution of the state. Politics was one area where the Reformation had an immediate and obvious impact (Rubin, 2017). Where the Reformation took hold, the ruling elite evicted the Catholic Church from power, thus fundamentally altering the governance system of Europe. Although political scientists and sociologists have long viewed this as one of the most important long-run effects of the

\footnotetext{
${ }^{6}$ Non-profit organizations are, of course, one of the central characteristics of the civil society; sometimes it is referred to as the "third sector" of society, distinct from government and business.
} 
Reformation, very few empirical research studies have examined how changes in political systems served as the pathway connecting the Protestant Reformation to long-run economic success.

Jared Rubin (2017) in his book, Rulers, Religion, and Riches, makes the case that when the ruling religious elite lost its power during the Reformation, the role of democratic parliaments has increased. Rubin argues that elected parliaments had interests that were more aligned with long-run economic development than the religious elite, and thus parliaments served as a catalyst for implementing economically beneficial laws. Daniel Nexon (2009) and Peter Stamatov (2010) pointed out that the Reformation also impacted the political structure of Europe by creating tight networks within parliaments which helped to overcome institutional barriers. Robert Woodberry (2012) highlighted the role Protestant missionaries played in influencing the rise and spread of stable democracy around the world. His statistical analysis showed that Protestant missions explain about half the variation in democracy in Africa, Asia, Latin America, and Oceania. Woodberry offers a number of causal mechanisms, including religious liberty, education, and printing press, through which Protestant missionaries were able to promote democracy in foreign countries.

In addition to impacting political systems, Harold Berman (2003) suggested that the Reformation affected the governance system of Europe through its effect on law. In his own words, the Protestant Reformation made a "revolution" in legal thinking and institutions. Berman argued that the legal reforms inspired by the Reformation laid the foundation of the "civic service state" characteristic of Western Europe. John Witte (2002), on the other hand, argued that Protestant legal innovations, such as protecting private property rights and contracts, were most effective in the economic sphere. Unfortunately, there is little current empirical evidence as to exactly what kind of Protestant legal innovations had a causal impact on long-run economic success of Western Europe. But as we stated before, there is consensus among political scientists and sociologists that the Protestant Reformation lead to significant changes in governance, politics and law, which in turn had a long-run impact on economic development of Western Europe.

\section{Conclusion}

The Protestant Reformation is a vivid example of how religious transformation could set in motion institutional changes, leading to profound consequences for economic and political development. Max Weber was the first to identify the significant role that the Reformation played in socio-economic development of Western Europe. He went as far as to state that the Reformation triggered a mental revolution that propelled the development of modern capitalism. In this chapter we 
showed that while most economists and other social scientists agree that the emergence of economic growth in Western Europe is closely tied to the Reformation, there is an active discussion as to what are the causal pathways connecting Protestantism to long-run economic success.

The first pathway is religious freedom. The Protestant Reformation in Europe has removed monopolistic rights on religion held by the medieval Roman Catholic Church, leading to the establishment of many Christian groups that ultimately became known as Lutherans, Presbyterians, Methodists, Baptists, Pentecostals, and many others. Religious freedom, of course, has been shown to reduce corruption and promote the protection of civil and human rights, which in turn has been shown to promote economic growth.

The second causal pathway connecting Protestantism to long-run economic success is education. Luther strongly encouraged reading the Bible, which in turn gave Protestants an early start on acquiring literacy and better education. Education increased labor productivity, fostered technological innovation and new knowledge creation, as well as brought other external benefits, all of which contributed to economic improvements.

Max Weber's main explanation for the economic success of Protestantism, which he proposed in his seminal work, The Protestant Ethic and the Spirit of Capitalism, was that Protestants had a different "work ethic." The studies that we reviewed in this chapter indeed provided empirical support to Weber's hypothesis, showing that Protestants value work more and work longer hours than other religious groups. Another famous claim that Max Weber made in his seminal work is that Protestantism was central to the rise of capitalism by encouraging entrepreneurship. Again, this hypothesis found substantial empirical support.

In addition to Weber's explanations, others have provided evidence that Protestants have a stronger "social ethic" which could be another pathway through which the Reformation impacted economic development. For example, we have discussed empirical research showing that Protestants have a higher level of trust and lower level of corruption, and both of these factors have been shown to promote economic growth. Related to "social ethic," academic researchers showed that Protestants are more engaged in civic activities. As an example, we looked at the United States of America, and pointed out that the formation of the American civil society was strongly influenced by Christian Protestant values. The rise of civil society was instrumental in economic development, because it lead to higher level of cooperation between people, lower corruption, and closer monitoring of the government. 
More recently, social scientists started to discuss the role that the Protestant Reformation played in the evolution of the state, giving rise to more democratic parliaments that served as a catalyst for implementing economically beneficial laws. Moreover, this had an additional external effect, as Protestant missionaries went around the world contributing to development of democracy in Africa, Asia, Latin America, and Oceania. While spreading the Gospel, Protestant missionaries were able to transform entire countries. 


\section{References}

Algan, Y., \& Cahuc, P. (2013). Trust and growth. Annual Review of Economics. 5, 521-549.

Allen, R.C. (2001). The great divergence in European wages and prices from the middle Ages to the First World War. Explorations in Economic History, 38, 411-447.

Amos, G.T. (1989). Defending the Declaration: How the Bible and Christianity influenced the writing of the Declaration of Independence. Wolgemuth \& Hyatt.

Anheier, H.K. (1989). Private voluntary organizations and development in West Africa: Comparative perspectives. In Jeames, E., (Ed.), The nonprofit sector in international perspective, New York: Oxford University Press, pp. 337-57.

Anheier, H.K., \& Salamon, L.M. (1998). The nonprofit sector in the developing world: A comparative analysis. Manchester, England: Manchester University Press.

Arrow, K. J. (1974). General economic equilibrium: purpose, analytic techniques, collective choice. American Economic Review, 64, 253-272.

Arrunada, B. (2010). Protestants and Catholics: Similar work ethic, different social ethic. Economic Journal, 120, 890-918.

Bai, Y., \& Kung, J.K. (2015). Diffusing knowledge while spreading God's message: Protestantism and Economic prosperity in China, 1840-1920. Journal of the European Economic Association, 13, 669-698.

Bainton, R.H. (1950). Here I stand: A life of Martin Luther. Abingdon Press, New York.

Barro, R., \& McCleary, R.M. (2003). Religion and economic growth across countries. American Sociological Review, 68, 760-781.

Barro, R.J. (1991). Economic growth in a cross section of countries. Quarterly Journal of Economics, 106, 407-443.

Basten, C., \& Betz, F. (2013). Beyond work ethic: Religion, individual, and political preferences. American Economic Journal: Economic Policy, 5, 67-91.

Becker, S.O., \& Woessmann, L. (2008). Luther and the girls: Religious denomination and the female education gap in nineteenth-century Prussia. Scandinavian Journal of Economics, 110, 777805.

Becker, S.O., \& Woessmann, L. (2009). Was Weber wrong? A human capital theory of Protestant economic history. Quarterly Journal of Economics, 124, 531-596.

Becker, S.O., Pfaff, S., \& Rubin, J. (2016). Causes and consequences of the Protestant Reformation. Explorations in Economic History, forthcoming.

Berman, H. (2003). Law and revolution, II: The impact of the protestant Reformations on the Western legal tradition. Harvard.

Bjornskov, C. (2007). Determinants of generalized trust: A cross-country comparison. Public Choice, $130,1-21$.

Blum, U. \& Dudley, L. (2001). Religion and economic growth: was Weber right? Journal of Evolutionary Economics, 11, 207-230.

Boppart, T., Falkinger, J., Grossmann, V., Woitek, U., \& Wüthrich, G. (2013). Under which conditions does religion affect educational outcomes? Explorations in Economic History, 50, 242-266.

Bresiger, G. (2014). Millions of Americans skipping lunch to work: study. New York Post, February, 2.

Burnham, T., McCabe, K., \& Smith, V.L. (2000). Friend-or-foe intentionality priming in an extensive form trust game. Journal of Economic Behavior \& Organization, 43, 57-73.

Card, D. (1999). The causal effect of education on earnings. In. Ashenfelter, O., \& Card, D., (Eds.), Handbook of labor economics. Amsterdam: North Holland, pp. 1801-1863. 
Chen, Y., Wang, H., \& Yan, S. (2014). The long-term effects of Protestant activities in China. Working paper, available at SSRN 2186818.

Clark, J.B. (1899). The distribution of wealth. New York and London: MacMillan.

Cook, K.S., Hardin,R., \& Levi, M. (2005). Cooperation without trust? Russell Sage Foundation.

Cuervo, A. (2005). Individual and environmental determinants of entrepreneurship. International Entrepreneurship and Management Journal, 1, 293-311.

Curtis, J.E., Baer, D.E., \& Grabb, E.G. (2001). Nations of joiners: Explaining voluntary association membership in democratic societies. American Sociological Review, 66, 783-805.

De Tocqueville, A. (2000 [1835]). Democracy in America. In Mansfield, H.C., \& Winthrop, D., (Eds.), Chicago: University of Chicago Press.

Dechenaux, E., Kovenock, D., \& Sheremeta, R. M. (2015). A survey of experimental research on contests, all-pay auctions and tournaments. Experimental Economics, 18, 609-669.

Delhey, J., \& Newton, K. (2005). Predicting cross-national levels of social trust: Global pattern or Nordic exceptionalism? European Sociological Review, 21, 311-327.

Deol, H. (2000). Religion and nationalism in India: The case of the Punjab. London: Routledge.

Ekelund, R., Hebert, R.F., \& Tollison, R.D. (2006). The marketplace of Christianity. Cambridge, MA: MIT Press.

Ekelund, R.B., Jr., Hebert, R.F., \& Tollison, R.D. (2006). The market for Christianity, Cambridge, MA: MIT Press.

Fama, E.F. (1970). Efficient capital markets: A review of theory and empirical work. Journal of Finance, 25, 383-417.

Ferguson, N. (2003). The world; Why America outpaces Europe (clue: The God factor). The New York Times, June, 8.

Fukuyama, F. (2001). Social capital, civil society and development. Third World Quarterly, 22, 7-20.

Gallego, F.A., \& Woodberry, R. (2010). Christian missionaries and education in former African colonies: How competition mattered. Journal of African Economies, 19, 294-329.

Gill, A. (1998). Rendering unto Caesar: the Catholic Church and the state in Latin America, Chicago.

Glaeser, E.L., Laibson, D.I., Scheinkman, J.A., \& Soutter, C.L. (2000). Measuring trust. Quarterly Journal of Economics, 115, 811-846.

Grim, B.J., \& Finke, R. (2011). The price of freedom denied. New York: Cambridge University Press.

Guiso, L., Sapienza, P., \& Zingales, L. (2003). People's opium? Religion and economic attitudes. Journal of Monetary Economics, 50, 225-282.

Hanushek, E.A. (2016). Will more higher education improve economic growth? Oxford Review of Economic Policy, 32, 538-552.

Hanushek, E.A., \& Kimko, D.D. (2000). Schooling, labor force quality, and the growth of nations. American Economic Review, 90, 1184-1208.

Hanushek, E.A., \& Woessmann, L. (2010) Education and economic growth. International Encyclopedia of Education, 2, 245-252.

Hanushek, E.A., \& Woessmann, L. (2012). Do better schools lead to more growth? Cognitive skills, economic outcomes, and causation. Journal of Economic Growth, 17, 267-321.

Hayek, F.A. (1937). Economics and knowledge. Economica, 4, 33-54.

Inglehart, R. (1999). Trust, well-being and democracy. In Warren, M. (Ed.), Democracy and trust, New York and Cambridge UK: Cambridge University Press, pp. 88-120.

James, E. (1986). The private nonprofit provision of education: a theoretical model and application to Japan. Journal of Comparative Economics, 10, 255-276.

James, E. (1989). The nonprofit sector in developing countries: The case of Sri Lanka. In The Nonprofit Sector in International Perspective, New York: Oxford University Press, pp. 289318. 
Knack, S., \& Keefer, P. (1997). Does social capital have an economic payoff? A cross-country investigation. Quarterly Journal of Economics, 112, 1251-1288.

Krueger, A.O. (1974). The political economy of the rent-seeking society. American Economic Review, 64, 291-303.

La Porta, R., Lopez-de-Silanes, F., Shleifer, A., \& Vishny, R.W. (1997). Trust in large organizations. American Economic Review, 87, 333-338.

Lam, P.Y. (2002). As the flocks gather: How religion affects voluntary association participation. Journal for the Scientific Study of Religion. 41, 405-422.

Lambert, F.T. (2003). The Founding Fathers and the place of religion in America. Princeton, NJ: Princeton University Press.

Lucas, R.E. (1988). On the mechanics of economic development. Journal of Monetary Economics, 22, 3-42.

Mankiw, N.G., Romer, D., \& Weil, D. (1992). A contribution to the empirics of economic growth. Quarterly Journal of Economics, 107, 407-437.

Mantovanelli, F.G. (2014). The Protestant legacy: Missions and literacy in India. Working paper, available at SSRN 2413170.

Martinussen, J. (2015). Society, state and market: A guide to competing theories of development. HSRC Publishers.

Mauro, P. (1995). Corruption and growth. Quarterly Journal of Economics, 110, 681-712.

McCarter, M.W., \& Sheremeta, R.M. (2013). You can't put old wine in new bottles: The effect of newcomers on coordination in groups. PLOS ONE, 8, 1-9.

McCleary, R.M. (2013). Protestantism and human capital in Guatemala and the republic of Korea. Working paper, available at SSRN 2239556.

McCloskey, D. (2010). Bourgeois dignity: Why economics can't explain the modern world. University of Chicago Press, Chicago.

Miller, K.D. (2002). Competitive strategies of religious organizations. Strategic Management Journal, $23,435-456$.

Mills, G. (2013). Working hours in Spain are too long. The Local, July, 4.

Moretti, E. (2004). Workers' education, spillovers, and productivity: evidence from plant-level production functions. American Economic Review, 94, 656-690.

Nexon, D. (2009). The struggle for power in early modern Europe: Religious conflict, dynastic empires, and international change. Princeton University Press.

Norris, P., \& Inglehart, R. (2004). Sacred and secular: Religion and politics worldwide. Cambridge University Press, New York.

North, C.M., Orman, W.H., \& Gwin, C.R. (2013). Religion, corruption, and the rule of law. Journal of Money, Credit and Banking, 45, 757-779.

Nunziata, L., \& Rocco, L. (2014), The Protestant ethic and entrepreneurship: Evidence from religious minorities from the former Holy Roman Empire. Working Paper.

Nunziata, L., \& Rocco, L. (2016). A tale of minorities: Evidence on religious ethics and entrepreneurship. Journal of Economic Growth, 21, 189-224.

Oberman, H.A. (1989). Luther: Man between God and the devil. Translated by Eileen WalliserSchwarzbart. New Haven: Yale University Press.

Oreopoulos, P., \& Salvanes, K.G. (2011). Priceless: The nonpecuniary benefits of schooling. Journal of Economic Perspectives, 25, 159-184.

Parker, S. (2005). The economics of entrepreneurship: What we know and what we don't. Foundations and Trends in Entrepreneurship, 1, 1-54. 
Pongsapich, A. (1998). The nonprofit sector in Thailand. In Anheier, H.K., \& Salamon, L., (Eds.), The nonprofit sector in the developing world, Manchester: Manchester University Press, pp. 294347.

Putnam, R.D. (1993). Making democracy work: Civic traditions in modern Italy. Princeton University Press, Princeton.

Rietveld, C.A., \& Van Burg, E. (2014). Religious beliefs and entrepreneurship among Dutch Protestants. International Journal of Entrepreneurship and Small Business, 23, 279-295.

Rietz, T.A., Sheremeta, R.M., Shields, T.W., \& Smith, V.L. (2013). Transparency, efficiency and the distribution of economic welfare in pass-through investment trust games. Journal of Economic Behavior \& Organization, 94, 257-267.

Romer, P. (1990). Endogenous technological change. Journal of Political Economy, 99, 71-102.

Rubin, J. (2017). Rulers, religion, and riches: Why the West got rich and the Middle East did not. Cambridge University Press.

Samuelsson, K. (1957). Religion and economic action: A critique of Max Weber. Toronto: University of Toronto Press.

Schniter, E., Sheremeta, R.M., \& Sznycer, D. (2013). Building and rebuilding trust with promises and apologies. Journal of Economic Behavior and Organization, 94, 242-256.

Schumpeter, J.A. (1942). Socialism, capitalism and democracy. New York: Harper and Brothers

Sheremeta, R.M. (2013). Overbidding and heterogeneous behavior in contest experiments. Journal of Economic Surveys, 27, 491-514.

Sheremeta, R.M. (2015). Behavioral dimensions of contests. In Congleton, R.D., \& Hillman, A.L., (Eds.), Companion to political economy of rent seeking, London: Edward Elgar, pp. 150-164.

Sheremeta, R.M. (2016). Impulsive behavior in competition: Testing theories of overbidding in rentseeking contests. Working Paper, available at SSRN 2676419.

Smith, V.L. (1962). An experimental study of competitive market behavior. Journal of Political Economy, 70, 111-137.

Solow, R.M. (1956). A contribution to the theory of economic growth. Quarterly Journal of Economics, 70, 65-94.

Spenkuch, J.L. (2016). The protestant ethic and work: Micro evidence from contemporary Germany. Working paper, available at SSRN 1722044.

Stamatov, P. (2010). Activist religion, empire, and the emergence of long-distance advocacy networks. American Sociological Review, 75, 607-628.

Stark, R., \& Iannaccone, L.R. (1994). A supply-side reinterpretation of the" secularization" of Europe. Journal for the Scientific Study of Religion, 33, 230-252.

Stulz, R.M., \& Williamson, R. (2003). Culture, openness, and finance. Journal of Financial Economics, 70, 313-349.

Tabellini, G. (2010). Culture and institutions: Economic development in the regions of Europe. Journal of the European Economic Association, 8, 677-716.

Treisman, D. (2000). The causes of corruption: A cross-national study. Journal of Public Economics, $76,399-457$.

Tullock, G. (1980). Efficient rent seeking. In Buchanan, J.M., Tollison, R.D., \& Tullock, G., (Eds.), Toward a theory of the rent-seeking society. College Station, TX: Texas A\&M University Press, pp. 97-112.

Uslaner, E.M. (2002). The moral foundations of trust. Cambridge University Press, Cambridge, UK.

Van der Veer, P. (2001). Imperial encounters: Religion and modernity in India and Britain. Princeton, NJ: Princeton University Press.

Van Hoorn, A., \& Maseland, R. (2013). Does a Protestant work ethic exist? Evidence from the wellbeing effect of unemployment. Journal of Economic Behavior \& Organization, 91, 1-12. 
Weber, M. (1905, 2002). The protestant ethic and the 'spirit' of capitalism. New York: Penguin.

Wills, G. (1979). Inventing America: Jefferson's Declaration of Independence. New York: Vintage Books.

Witte, J. (2002). Law and Protestantism: The legal teachings of the Lutheran Reformation. Cambridge University Press.

Woodberry, R.D. (2004). The shadow of empire: Christian missions, colonial policy, and democracy in post colonial societies. PhD dissertation, University of North Carolina at Chapel Hill.

Woodberry, R.D. (2012). The missionary roots of liberal democracy. American Political Science Review, 106, 244-274.

Zak, P.J., \& Knack, S. (2001). Trust and growth. Economic Journal, 111, 295-321. 